\title{
Investment Aspects of Overcoming the Digital Inequality of Constituent Entities of the Macro-Region
}

\author{
Kvon G.M.* Pozdeeva O.G. Titovets A.Yu. \\ Ural State Economic University, Yekaterinburg, Russia \\ *Corresponding author. E-mail:sung2002@mail.ru
}

\begin{abstract}
The relevance of the problem studied in the article is due to the fact that modern economic conditions are characterized by the active influence of the processes of Informatization and digitalization, which affect investment processes, but the issues of existing differentiation and inequality of regions in development, including digital, require more careful consideration. The main goal of implementing the concept of spatial development of Russia, approved in February 2019, is [1] to overcome inequality in the level of economic development of regions. Inequality in the economic development of regions is largely due to the territorial features formed under the influence of trends in the spatial development of the country. The presence of significant regional differentiation inevitably leads to the formation of digital inequality in regions.

The purpose of the article is to study the investment aspects of digital inequality of entities in the UralSiberian macro-region and their overcoming in the General context of regional differentiation. The leading method in the study is the method of comparative analysis, which characterizes the dynamics of the development of subjects based on comparative values.

The article presents the results of analysis and evaluation of a number of indicators that characterize the investment policy of regions in the field of ICT, as well as indicators that allow us to determine the differentiation of macroregion subjects, both in terms of their overall economic development and in the field of digital inequality. Based on the analysis of indicators reflecting regional development trends in the field of information, communication and digital technologies, it is concluded that in general the macroregion has a certain potential for development in the field under study.
\end{abstract}

Keywords: macroregion, investment policy of the region, information and communication technologies,

economic inequality, digital inequality, financing of informatization activities

\section{INTRODUCTION}

The social and economic development of Russian regions, largely determined by the investment policy being implemented, actualizes the issues of increasing their investment activity. However, the current negative conditions of non-stationarity, slowing down the growth rate of the country's economy, make it difficult to form an investment environment. The existing differentiation of regions [2] causes different rates of their economic, social and other characteristics of development [3].

The problem of development inequality among territories has been studied for quite a long time, so A. Smith and D. Ricardo have justified inequality through absolute and comparative advantages, and in the works of $\mathrm{H}$. Richardson it is determined that the distribution of benefits from the development advantage occurs unevenly between regions, increasing the existing inequality [4].

Studies of economic inequality have shown that there is a conflict between economic development (growth) and inequality, since the potential for increasing economic inequality is a consequence of economic growth. In the long run, the above limits the prospects for development, since economic development does not necessarily reduce economic inequality and may even increase it [5].

The disintegration of Russian regions is largely due to the heterogeneity of the economic environment, which was most clearly manifested in the early 90 s of the twentieth century in connection with the introduction of market relations in the country.

Russian scientists pay much attention to the issues of differentiation of territorial development. For the analysis of interregional inequality, domestic researchers use various indicators, such as the gross regional product and income of the population, noted in the work of Glazyrina I. P., Klevakina E. A [6]., Malkina M. Yu. [7], the level of poverty, unemployment, the distribution of investment (Zubarevich N. V., Safronov S. G.). [8]. The influence of industries and types of economic activity on interregional inequality was considered in the works of B. L. Lavrovsky and E. A. Shiltsin [9], D. S. Ivanov [10]. 
Regional differentiation is due to both subjective and objective reasons, so P. Krugman [11] identified two groups of factors that affect the development of regions: "the first nature" (natural resources, geographical location) and "the second nature" (the result of human activity). Given that regional differentiation in Russia significantly depends on the availability of natural resources in the regions, it is among the entities of the Ural-Siberian macroregion that this dependence is clearly evident.

The importance of the study of regional economic inequality is due to the influence of this aspect on the development and implementation of many projects required by the country, and in combination with digital inequality and digital development trajectories, leads to inefficiency of investment measures.

Digital inequality as a research category appeared in the mid-90s, the greatest public interest in it was shown after the G8 summit in 2000. This is due to the fact that at first ICT was perceived as a factor that contributes to reducing inequality between territories, due to the possibility of including remote territories in the economic process, but later the uneven spread of ICT [12] led to an uneven impact on regional economic development [13]. That is, the existing economic imbalance between territories has formed the development of digital inequality, which in turn increases regional economic inequality, since digital dividends are deposited in a small number of regions, companies and individuals [14].

Accordingly, digital inequality is a gap that separates those who have access to new information technologies from those who do not have this access [15]. After all, moving any activity to the electronic field requires a certain level of development of information technologies and opportunities to use the advantages of these technologies. Thus, the problem of digital inequality has become extremely important for many international organizations, politicians and scientific organizations (Wyatt et al., 2000, Robins and Webster, 1999; Fuchs, 2008; Billon, Marco \& Lera Lopez, 2009) [16,17,18,19,20]. In addition, the transition to a new technological order requires the development of information and digital technologies, which leads to the fact that digital inequality is more pronounced and will lead to additional regional disparities and problems. Therefore, it is necessary to direct investment flows to projects that may initially be economically unprofitable, but to create a popular and working infrastructure.

The difficulty in studying digital inequality and determining its relationship with economic processes lies in the current lack of a unified approach to understanding and calculating digital inequality in international and Russian practice. This is primarily due to the fact that researchers use different (contradictory) research objects, determinants, and factors, which is expressed in different research questions, approaches, and recommendations $[21,22]$. Therefore, digital inequality is considered and expressed in three levels [15,23]:

- availability of ICT - ability to connect and use ICT;
- $\quad$ literacy and skills-level of ICT proficiency;

- use or implementation of ICT.

It is important to note that, as well as the study of levels of digital inequality, and the impact on the territory, manifests itself in stages, so for the regions of the Russian Federation, it is important to study the availability of ICT. And it is important to look at the availability of information technologies, and not just the availability of infrastructure, because we wanted to consider digital inequality as an independent category, and based on existing digital inequalities to consider its relationship with the economic inequality of territories.

In market conditions, however, there are various strategies for the development and use of IT, which is associated with investing in this area. It should be noted that depending on the level of regions (and countries), these strategies provide for different use of information technologies, respectively, providing different amounts of funding.

In the article by Narcyz Roztocki and H. Roland Weistroffer [24], the authors consider the factors that, in their opinion, most likely affect the effect of investment in ICT, as well as the positive impact of ICT on socioeconomic development. In the same connection, the authors talk about the need to develop entrepreneurial activities necessary for socio-economic development. These activities include e-Commerce, online and mobile social networks, navigation systems, E-government, online and mobile broadcasting, online learning, and communication networks such as email, text messages, tweets, and blogs. The development of ICT has a huge infrastructural significance, allowing the development of the social sphere (medicine, education), as well as the life support industry. However, according to Kowal J. and Roztocki N [25], which are referred to by the authors, in many developing regions there is no favorable business culture and legal framework for successful business activities, appropriate public policies, and the infrastructure necessary for the development of ICT is also missing.

The methodology of research on ICT investments and their relationship to macroeconomic results, which is consistent with the assumptions of the neoclassical growth accounting system, is presented in the work of authors Samoilenko, S., and Osei-Bryson, K.-M. [26] concerning countries with economies in transition. The authors conclude that investment in ICT can affect macroeconomic outcomes, and this applies not only to transition countries, but also to developed countries. Earlier, Samoilenko [27] identified 15 factors that affect the level of efficiency of investment in telecommunications. These factors reflect differences in the level of economic development, the level of investment in telecommunications, the level of accumulated telecommunications capital, as well as the level of use of telecommunications capital, the level of socio-technical development and the level of militarization. In a later paper published in collaboration with Kweku-Muata Osei-Bryson [28], he summarizes his research on transition economies and says that the existing 
investment-income model works if a threshold level of ICT capital infrastructure has been developed; at the same time, the return on investment in ICT and its conversion into income directly depends on the quality of the full-time workforce in this area.

\section{METHOD OF DATA ANALYSIS}

The methodology of the research is presented by a number of procedures that are reflected in this work. The methods used include:

- methods for collecting and summarizing statistical information;

- $\quad$ comparative and retrospective methods;

- method of comparative analysis based on average indicators;

- $\quad$ methods of analysis and synthesis;

- methods for tabular and graphical visualization of the presented data.

The subjects of the Ural-Siberian macroregion that coincide in their component composition with the subjects of the Ural Federal district are accepted as the object of research.

\section{RESULTS}

To assess the differentiation of regions, the authors used a method of comparative analysis based on average indicators that characterize the economic development of the subjects of the Russian Federation. The calculation was based on 11 basic economic indicators.

To determine the degree of differentiation the ranking in ascending order of the achieved level was used. The lowest rank was assigned to the higher value for each indicator and then the integral index of regional economic development was calculated. The results of the assessment showed that the regions of the Ural-Siberian macroregion are characterized by significant differentiation in the level of economic development. In 2018, the Yamalo-Nenets and Khanty-Mansi Autonomous okrugs had the highest level of economic development, which significantly outperformed other regions. The authors found that the integral index was 15 for Yamalo-Nenets Autonomous district and 21 for Khanty-Mansi Autonomous district. High values for the main economic indicators in these regions of the Russian Federation are due to the fact that they are resource regions and high prices, as well as constantly increasing demand for oil and natural gas in the world economy, provided investment attractiveness and economic growth in these regions. A strong middle position is occupied by regions with a predominant development of manufacturing industries-Tyumen, Sverdlovsk and Chelyabinsk regions (integral index, respectively, 32, 41 and 51).

The most lagging region in terms of economic development is the Kurgan region (integral index-66). According to absolutely all indicators used in the calculation, it takes the last place. The low level of economic development is due to the fact that the Kurgan region is an industrial and agricultural territory and a relatively high share in the creation of GRP belongs to agricultural production, which does not bring a high rate of profit.

The study also showed that in comparison with 2015, inequality in the level of economic development of the subjects of the Ural-Siberian macroregion has increased. Yamalo-Nenets, Khanty-Mansi Autonomous okrugs and the Tyumen region improved their economic situation, while other regions decreased their positions. As a result, the gap between regions has widened (figure 1).

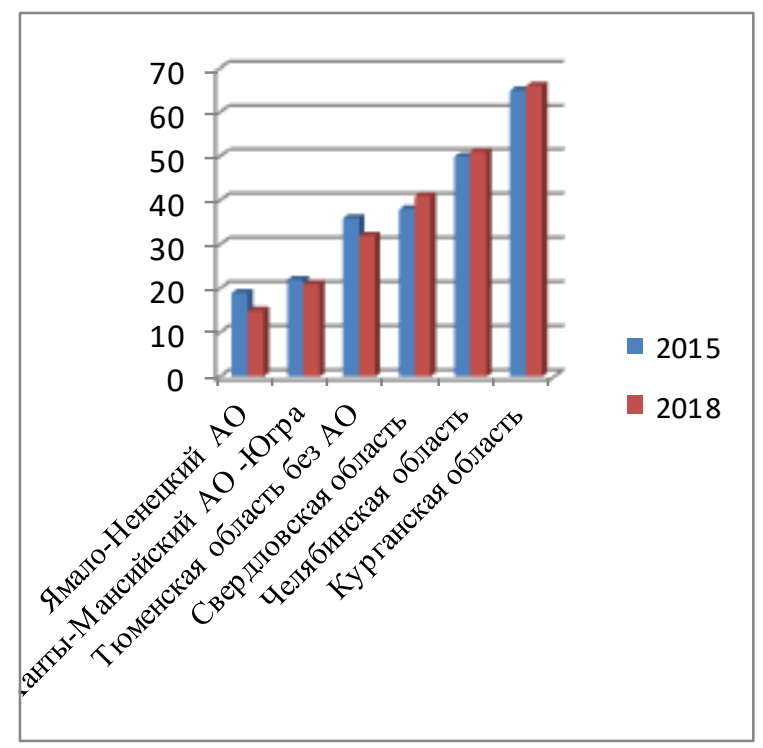

Figure 1 Integrated index of economic development of the subjects of the Ural-Siberian macroregion for 2015 and 2018

The rating of the socio-economic status of the subjects of the Russian Federation conducted by RIA [29 ]generally confirms the results of the research. Thus, the rating of the regions of the Ural-Siberian macroregion (UrFO), conducted by the Agency according to such criteria as socio-economic status, shows the following positions of the subjects of the macroregion in 2018 (table 1). 
Table 1 Integral rating of socio-economic status of the Ural-Siberian macro-region subjects for 2018 [29]

\begin{tabular}{|c|c|c|c|}
\hline \multirow{2}{*}{ The subject of the macro-region } & \multicolumn{2}{|l|}{2018} & \multirow{2}{*}{$\begin{array}{l}\text { Rating by macro } \\
\text { region }\end{array}$} \\
\hline & $\begin{array}{l}\text { Place in the Russian } \\
\text { Federation, para. }\end{array}$ & Integral rating, points & \\
\hline Sverdlovsk region & 7 & 67,91 & 3 \\
\hline Kurgan region & 76 & 23,948 & 6 \\
\hline Chelyabinsk region & 15 & 57,264 & 5 \\
\hline Tyumen region & 8 & 64,934 & 4 \\
\hline KhMAO & 3 & 78,398 & 1 \\
\hline YANAO & 6 & 69,388 & 2 \\
\hline
\end{tabular}

The data from the table indicates a fairly stable position of subjects in the overall rating of the Russian Federation with the exception of the Kurgan region. 4 out of 6 regions are in the top 10 regions in terms of their socio-economic status.

The dynamics of the rating compiled according to RIA data for the period 2015-2018 [29] is shown in figure 2 .

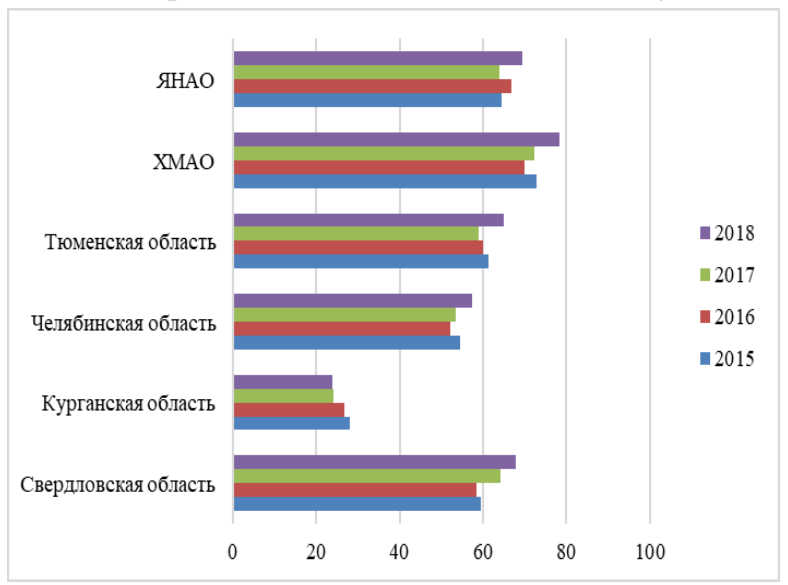

Figure 2 Dynamics of the integrated rating of socioeconomic status of the subjects of the Ural-Siberian macroregion for 2015-2018 [29]

The dynamics of the indicator for the study period shows an improvement in the positions of subjects, with the exception of the Kurgan region, which in principle confirms the hypothesis of increasing differentiation of subjects for the worse, which were already in the last positions (or close to them) compared to other regions.

For Russia the digital inequality as well as the economic one manifests itself by a strong contrast between center and periphery, since the availability of information technology in major centres is much higher (information luxury), while in the periphery there are only minimum conditions for the development and use of IT. Therefore, for Russian regions, digital inequality is formed not from the unavailability or inability to use information technologies, but from the lack of availability of information technologies.if a subject does not have the Internet or its cost is high, they will not be able and will not use information technologies. At the same time, it is necessary to understand accessibility not only as a technical possibility, but also as a cost one, since it may be cheaper for many citizens and organizations to operate without using information technology.

Therefore, to calculate availability, you need to evaluate two main parameters: speed and cost of the Internet. For calculations, data from open sources of information were selected: speed - data from Rostelecom (the largest player in the Russian market and with representation in all regions of the Russian Federation) and the Speedtest website (the largest organization that measures data around the world) were considered; cost-package offers from Rostelecom (table 2). 
Table 2 Data on Internet speed and cost for the Ural-Siberian macroregion, 2018 [30,31]

\begin{tabular}{|c|c|c|c|c|}
\hline & \multicolumn{2}{|l|}{ Rostelecom } & \multicolumn{2}{|l|}{ Speedtest } \\
\hline & Speed Mbit / s & Cost, rubles & $\begin{array}{l}\text { Speed (broadban), Mbit } \\
\text { / s }\end{array}$ & $\begin{array}{l}\text { Speed (Mobile } \\
\text { access), Mbit / s }\end{array}$ \\
\hline Kurgan region & 100 & 400 & 30,47 & 12,14 \\
\hline Sverdlovsk region & 110 & 400 & 37,44 & 14,33 \\
\hline KhMAO & 90 & 650 & 57,27 & 11,55 \\
\hline YANAO & 90 & 1500 & 49,44 & 9,43 \\
\hline Tyumen region & 100 & 500 & 41,24 & 14,66 \\
\hline Chelyabinsk region & 130 & 250 & 47,44 & 16,37 \\
\hline $\begin{array}{l}\text { Max. value for the } \\
\text { Russian Federation }\end{array}$ & 200 & - & 57,27 & 29,02 \\
\hline
\end{tabular}

To form a single indicator for evaluating digital inequality, all values on a scale from 0 to 1 were normalized based on the maximum necessary and possible level of achievement for these values: speed-calculated as the average value among all speed indicators; the cost calculations have been made on the installation, which in modern terms spending on the Internet is becoming mandatory for life and therefore needs to understand what is the share of the subsistence level, the calculation is in the inverse, since it is necessary to strive not to the maximum, but to the minimum (table 3).

Table 3 Calculation of the digital inequality indicator based on the speed and cost of Internet access for the Ural-Siberian macroregion, 2018 [30,31]

\begin{tabular}{|c|c|c|c|c|c|}
\hline & The calculation of & st index & & & \\
\hline & $\begin{array}{l}\text { Min cost of living, } \\
\text { RUB. }\end{array}$ & Share, \% & Cost index & Cost index & Index \\
\hline Kurgan region & 9387 & 4,26 & 0,57 & 0,48 & 0,53 \\
\hline Sverdlovsk region & 10217 & 3,92 & 0,61 & 0,57 & 0,59 \\
\hline KhMAO & 14471 & 4,49 & 0,55 & 0,62 & 0,58 \\
\hline YANAO & 15538 & 9,65 & 0,03 & 0,55 & 0,29 \\
\hline Tyumen region & 10450 & 4,78 & 0,52 & 0,58 & 0,55 \\
\hline Chelyabinsk region & 9330 & 2,68 & 0,73 & 0,68 & 0,71 \\
\hline $\begin{array}{l}\text { Max. value for the Russian } \\
\text { Federation }\end{array}$ & - & 10 & - & - & - \\
\hline
\end{tabular}

The obtained values show how heterogeneous the regions are according to these indicators, the Chelyabinsk region is in the best position, the YANAO has the worst indicator, and the gap within one macroregion is $40 \%$. At the same time, it can be noted that the obtained data on speed and availability do not always depend on the overall economic state of the regions. Thus, despite the fact that according to many ratings, the position of the YANAO is rated as one of the highest positions in the region, in this case the region demonstrates low availability of it (figure $3)$. 


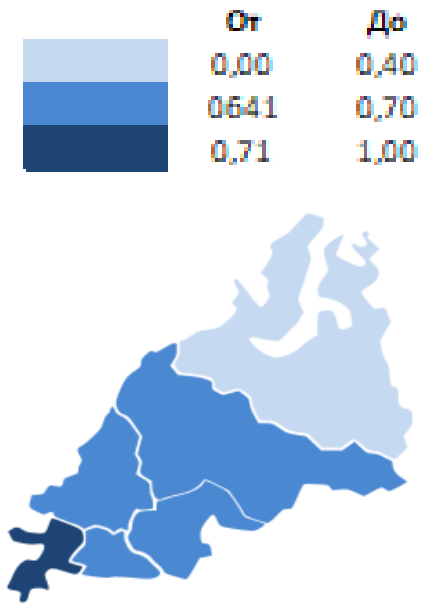

Figure 3 Indicator of digital inequality in the UralSiberian macroregion

When forming investment decisions and evaluating the direction of investment flows, it is necessary to understand that economic inequality is manifested in material resources and material disadvantage (poverty), digital inequality is manifested in the availability of information resources (information technologies) and the price possibility of their use.

Therefore, taking into account all the existing opportunities and prospects for development due to information technologies, the main barrier to all processes is the availability of information technologies.

In this regard, we consider it necessary to examine investment aspects of regional development that also affect the development of the IT sector.

Let's consider the main indicator of investment activity in the macroregion in the context of its constituent entities, considering such an indicator as investment in fixed capital by region.

The dynamics of investment in fixed assets for the subjects of the macroregion, compiled according to official statistics [32], is shown in figure 4.

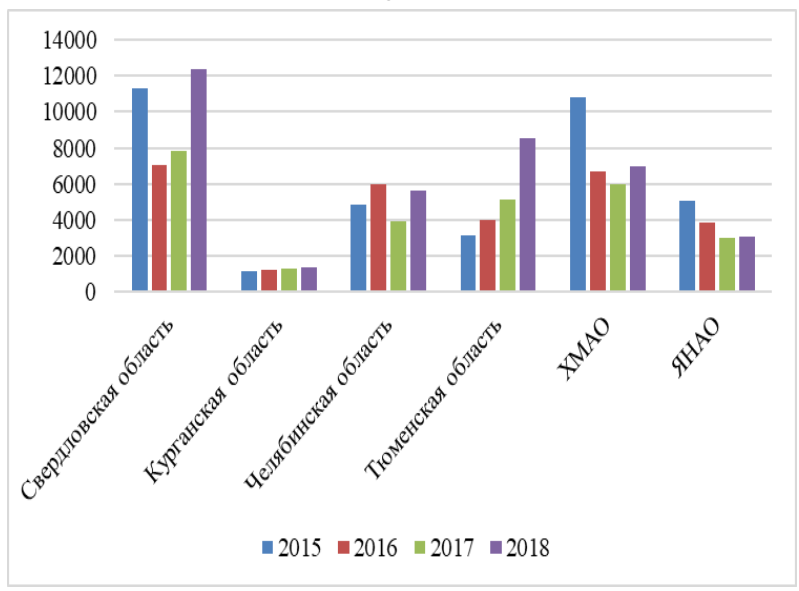

Figure 4 Dynamics of investment in fixed assets in the Ural-Siberian macro-region for 2015-2018, million rubles [32]
Despite the fact that the total amount of investment over the years has a positive trend (a slight decrease was observed in 2015 as a consequence of the negative crisis events in 2014), the overall situation in the macroregion is positive.

According to the analytical data reflecting the situation with Informatization of regions [33], we have compiled a summary chart showing the dynamics of regional expenditures for these purposes for the period 2015-2018. (figure 5) and dynamics of specific indicators (per 1000 people) for the subjects for the same period (figure 6).
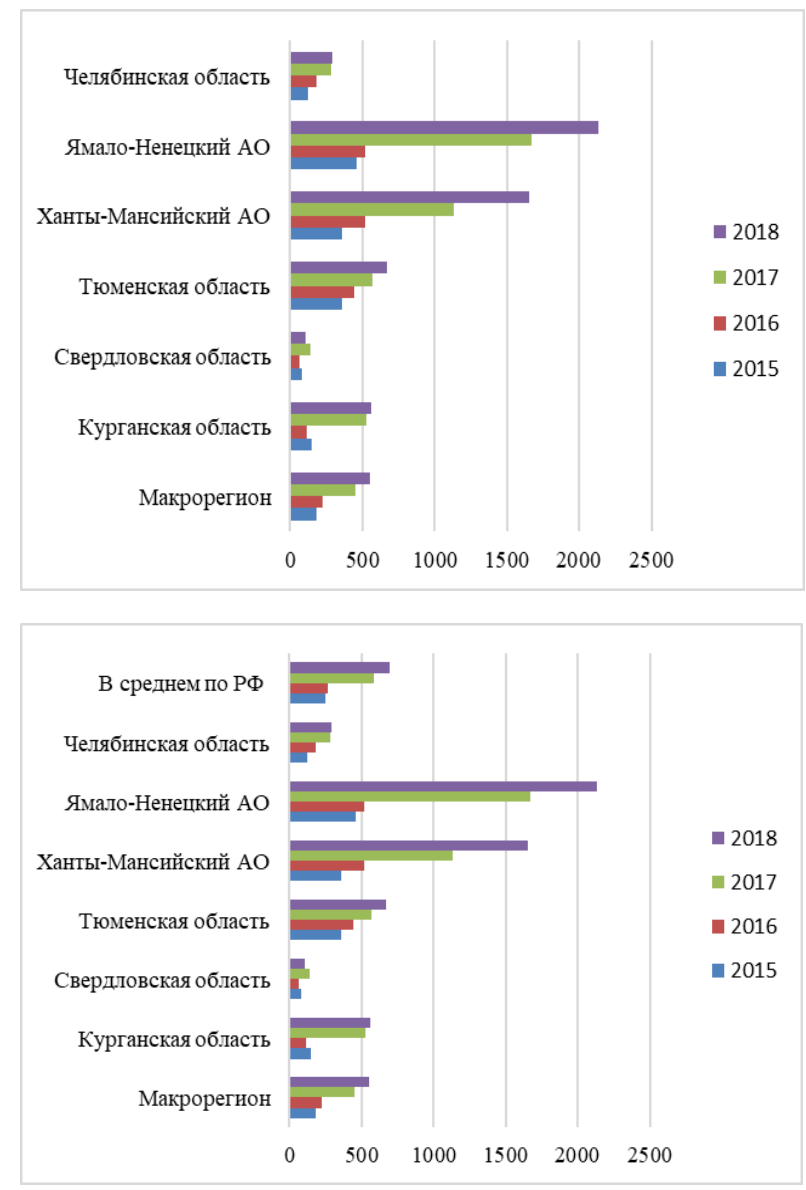

Figure 5 Dynamics of the volume of financing per 1000 people for 2015-2018 for the macroregion and on average for the Russian Federation, thousand rubles

As can be seen from figure 6, the specific amount of funding for Informatization activities is uneven across regions, but the average values for the macroregion and the Russian Federation as a whole are very close. The macroregion as a whole and its subjects repeat the trend of the Russian Federation, which is characterized by a sharp increase in investment per 1000 people in 2017 and 2018. It is difficult to identify the trend of deviation in the dynamics of the average values of the studied indicator for the Sverdlovsk region in 2018 (the specific value is lower than in 2017), but in General, the region is characterized by extremely positive dynamics in terms of the total 
on February 13, 2019 URL: http://static.government.ru/media/files/UVAlqUtT08o6 ORktoOX122JjAe7irNxc.pdf [Last retrieved on 2020 March]

[2] T.V. Starikova, Development of the typology of regions in the strategic planning system. Economics in Industry, 2017, T. 10, No. 2, p. 172-178.

[3] G.M. Kvon, Regional aspects of the development of the investment potential of the Ural macro-region. Regional problems of economic transformation, 2019, 9 (107), p. 51-60.

[4] Handbook of regional and urban economics. Edited by P. Nijkamp, Free University. Amsterdam, 1986

[5] M.I. Shahateet. How Serious Regional Economic Inequality in Jordan? Evidence from Two National Household Surveys. American Journal of Applied Sciences, 2006, 3 (2), pp. 1735-1744.

[6] I.P. Glazyrina, E.A. Klevakin, Income inequality, pace and quality of economic growth in Russian regions. In the collection: XIV April international scientific conference on the problems of economic and social development in 4 book. - M .: HSE Publishing House, 2016, S. 41-54

[7] M.Yu. Malkin, A study of the factors of interregional convergence / divergence of real incomes and "social well-being" of the regions of the Russian Federation, Journal of Economic Regulation, 2016, V. 6, No. 4., p. 111-119.

[8] N.V. Zubarevich, S.G. Safronov, Inequality of socio-economic development of regions and cities of Russia in the 2000s: growth or decline ?. Social Sciences and the Present, 2013, No. 6., p. 15-26.

[9] D. S. Ivanov, The role of the services sector in regional inequality of employment and wages in the 2000s. Regional Studies, 2011, No. 1, p. 91-98.

[10] B. L. Lavrovsky, E. A. Shiltsin, Russian regions: rapprochement or stratification ?. Economics and Mathematical Methods, 2009, T. 45., No. 2., p. 31-36..

[11] P. R. Krugman, Increasing Returns and Economic Geography. The Journal of Political Economy - The University of Chicago Press, 1991, Vol. 99, No. 3, pp. 483-499.

[12] F. Mubarak, Towards a renewed understanding of the complex nerves of the digital divide, Journal of Social Inclusion, 2015, Vol. 6 No. 1, pp. 71-U104.
[1] The spatial development strategy of the Russian Federation for the period until 2025 (2019), approved by order of the Government of the Russian Federation 
[24] N. Roztocki, H. R. Weistroffer, Conceptualizing and Researching the Adoption of ICT and the Impact on Socioeconomic. Development Information Technology for Development, 2016, Vol.22, No.4, pp. 541-549

[25] J. Kowal, N. Roztocki, Information and communication technology management for global competitiveness and economic growth in emerging economies. The Electronic Journal of Information Systems in Developing Countries, 2013, 57, pp. 1-12

[26] S. Samoilenko, K.-M. Osei-Bryson, Linking investments in telecoms and total factor productivity in transition economies. Proceedings of the 18th European conference on information systems, Pretoria, South Africa, 2010, June 6-9

[27] S. Samoilenko, Contributing factors to information technology investments utilization in transition economies: An empirical investigation. Information Technology for Development, 2008, 14 (1), pp. 52-75

[28] S. Samoilenko, K.-M. Osei-Bryson, Human Development and Macroeconomic Returns within the Context of Investments in Telecoms: An Exploration of Transition Economies. Information Technology for Development, 2013, Volume 22, 2016 - Issue 4, pp. $550-551$

[18] R. Kevin, F. Webster, Times of the Technoculture: From the Information Society to the Virtual Life, London: Routledge, 1999, 307 pp.

[19] M. Billon, R. Marco, F. Lera-Lopez, Disparities in ICT adoption: A multidimensional approach to study the cross-country digital divide. Telecommunications Policy, 2009, 33 (10-11), pp. 596-610.

[20] Digital Divide: the Internet and social inequality in international perspective / ed. by M. Ragnedda, G. W. Muschert, Routledge, 2013, 324 p.

[21] L. Yu, The divided views of the information and digital divides: a call for integrative theories of information inequality, Journal of Information Science, 2011, Vol. 37 No. 6, pp. 660-679.

[22] B. Yu, A. Ndumu, L. Mon, Z. Fan, E-inclusion or digital divide: an integrated model of digital inequality, Journal of Documentation, 2018, Vol. 74 No. 3, pp. $552-574$

[23] A.A. Gladkova, V.Z. Garifullin, R. Massimo, A Model of Three Levels of Digital Inequality: Modern Opportunities and Limitations (Case Study of the Republic of Tatarstan). Bulletin of Moscow University. Series 10. Journalism, 2019, No. 4, p. 41-72
[29] Integrated Economic Development Index according to RIA Access mode: http://vid1.rian.ru/ig/ratings/rating_regions_2016.pdf, https://riarating.ru/infografika/20190604/630126280.ht $\mathrm{ml}$

Russian International Information Agency "RIA Novosti". URL: https://ria.ru

[30] The official website of the company Rostelecom. URL: https://www.company.rt.ru

[31] The official website of Speedtest. URL: https://www.speedtest.net

[32] Federal State Statistics Service of the Russian Federation. URL: https://www.gks.ru/investment_nonfinancial

[33] Informatization of regions. Russian market. ICT expenses of Russian regions in 2018. Rating. Analytical review. URL: http://www.tadviser.ru/index.php. Date of circulation 03/12/2020. 